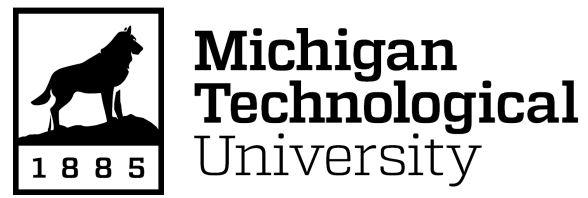

Michigan Technological University Digital Commons @ Michigan Tech

Dissertations, Master's Theses and Master's Reports

2019

\title{
KEWEENAW FAULT GEOMETRY AND SLIP KINEMATICS - BÊTE GRISE BAY, KEWEENAW PENINSULA, MICHIGAN
}

Colin Tyrrell

Michigan Technological University, cwtyrrel@mtu.edu

Copyright 2019 Colin Tyrrell

Recommended Citation

Tyrrell, Colin, "KEWEENAW FAULT GEOMETRY AND SLIP KINEMATICS - BÊTE GRISE BAY, KEWEENAW PENINSULA, MICHIGAN", Open Access Master's Report, Michigan Technological University, 2019.

https://doi.org/10.37099/mtu.dc.etdr/947

Follow this and additional works at: https://digitalcommons.mtu.edu/etdr

Part of the Geology Commons 


\title{
KEWEENAW FAULT GEOMETRY AND SLIP KINEMATICS - BÊTE GRISE BAY,
} KEWEENAW PENINSULA, MICHIGAN

By

Colin W. Tyrrell

\begin{abstract}
A REPORT
Submitted in partial fulfillment of the requirements for the degree of

MASTER OF SCIENCE

In Geology
\end{abstract}

MICHIGAN TECHNOLOGICAL UNIVERSITY

2019

(C) 2019 Colin W. Tyrrell 
This report has been approved in partial fulfillment of the requirements for the Degree of MASTER OF SCIENCE in Geology.

Department of Geological and Mining Engineering and Sciences

\author{
Report Advisor: James M. DeGraff
}

Committee Member: Chad D. Deering

Committee Member: Jeremy M. Shannon

Committee Member: $\quad$ William A. Rose

Department Chair: John S. Gierke 


\section{Table of Contents}

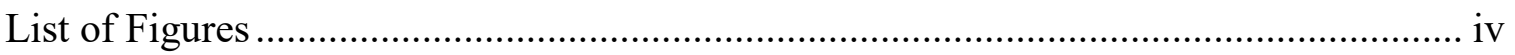

Acknowledgements ................................................................................................... vi

List of abbreviations ............................................................................................. vii

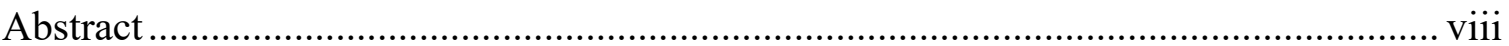

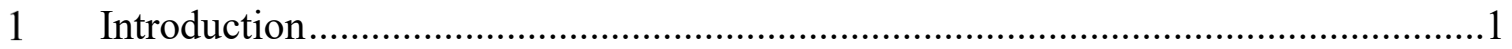

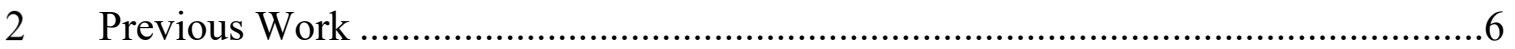

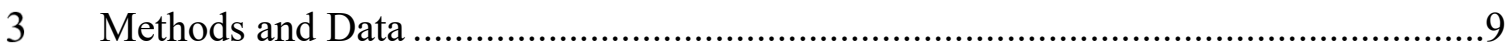

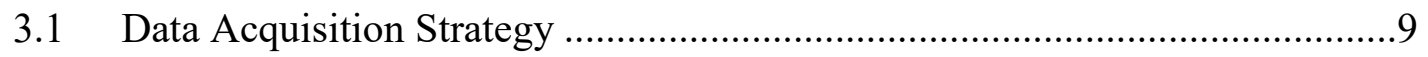

3.2 Field Geological Mapping ......................................................................

$3.3 \quad$ Field Geophysical Work..........................................................................

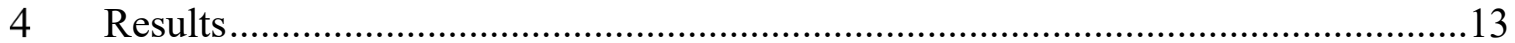

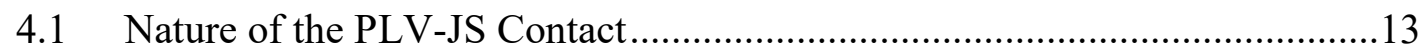

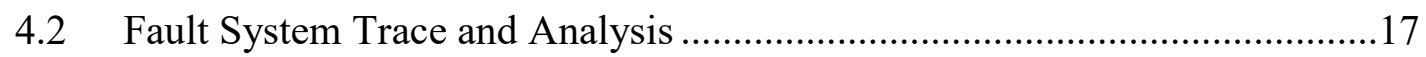

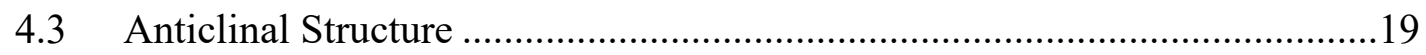

4.4 Timing of fault movement .........................................................................22

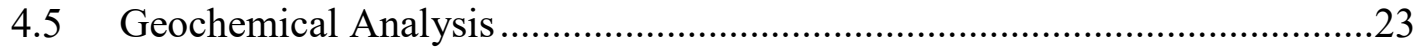

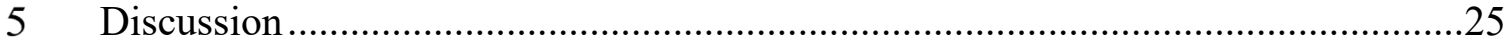

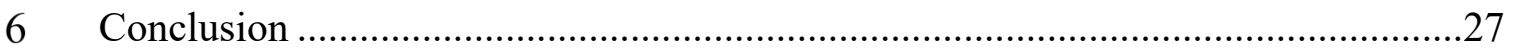

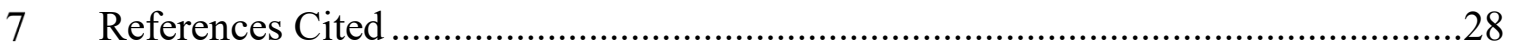




\section{List of Figures}

Figure 1. Keweenawan geology of the Midcontinent Rift System in the Lake Superior Basin (Miller and Nicholson, 2013). Credit: Precambrian Research Center Guidebook 13-01, p. 5.

Figure 2. Parts of two USGS geological maps covering the Bête Grise Bay - Big Bay area of the Keweenaw Peninsula, Michigan (Cornwall, 1954; Cornwall, 1955). Credit: U.S. Geological Survey, Department of the Interior/USGS.

Figure 3. U.S.G.S. geological map of the study area (Cornwall, 1954; Cornwall, 1955). Note the sinuous path of the KF trace denoted as a black solid, dashed, and dotted line. Rock units: basalt - green, rhyolite - red, conglomerate - orange, Jacobsville Sandstone - maroon. Credit: U.S. Geological Survey, Department of the Interior/USGS.

Figure 4. Anticlinal structure of the Keweenaw Peninsula as interpreted by Foster and Whitney (1851). Red circle highlights their interpretation of SW dips on the south side of the peninsula. Credit: U.S. Geological Survey, Department of the Interior/USGS.

Figure 5. Cross section of thrust fault across Keweenaw Peninsula, Lake Medora Quadrangle, Section B - B', Cornwall (1954). See Figure 3 for location. Note the more steeply dipping beds of JS closer to the fault. Credit: U.S. Geological Survey, Department of the Interior/USGS

Figure 6. Keweenaw Fault system along Bête Grise Bay area of Keweenaw Peninsula. Faults denoted with bold black lines, bold dotted lines. Rock unit colors: basalt green, rhyolite - red, conglomerate orange and brown, JS - yellow (DeGraff, 2018). Credit: U.S. Geological Survey, Department of the Interior/USGS...........13

Figure 7. New fault pattern from analysis of mapping data and interpretation of variation in orientation of bedding planes. Faulted anticline lies southwest of Bare Bluff. Rock unit colors: basalt - green, rhyolite - red, conglomerate - light and dark brown, JS - yellow.

Figure 8. Faulted contact between PLV (right) and JS (left). Look direction is westward and subparallel to the fault. Deformation as defined by brecciation and veining is more intense in PLV than in JS

Figure 9. Unconformity at west side of subarea \#4. The basalt dips $\sim 38^{\circ}$ SE and JS dips $\sim$ $25^{\circ} \mathrm{SE}$.

Figure 10. East side of SA \#3 showing shoreline unconformity at PLV - JS contact. Horizontal JS overlies basalt north and south of a fault zone with anastomosing 
shear bands cutting a basalt breccia. Look direction is westward. See Figure 7 for

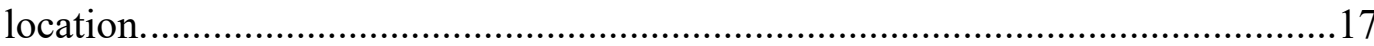

Figure 11. Radial histogram of rakes of fault lineations define the fault as predominantly strike-slip. Black arrow denotes arithmetic mean of data.......................................18

Figure 12. FaultKin plot using fault planes, rake lineations, and sense of slip to compute three principal axes of deformation. The principal shortening direction, given by axis \#3 and projected onto a horizontal plane, is along a line with azimuth $117^{\circ}$ $297^{\circ}$

Figure 13. Poles of bedding planes (small dots) in the fold area southwest of Bare Bluff (Figure 7 for location). Pole \#3 is the fold axis of the anticline. Stereonet, 20112016

Figure 14. Cross section through the Bare Hill area constructed perpendicular to structural trend. (Figure 11 for location). USGS strike and dips constrain north side of the section from the Bohemia conglomerate south to the rhyolite body. Thick solid black line denotes mapped fault, thick dashed black lines denote interpreted faults, thin black lines are form lines of bedding within basalt. Rock unit colors: basalt - green, rhyolite - red, conglomerate - brown, sandstone yellow, Lake Superior - light blue at far right.

Figure 15. Rare-earth element plot. (Schultz, K., 2018). Green triangles represent the plot of our samples that are compositionally similar PLV from other areas. Credit: U.S. Geological Survey, Department of the Interior/USGS. 


\section{Acknowledgements}

I would like to thank my advisor James M. DeGraff for his guidance through the preparation, execution, and analysis of this research project. I would also like to thank Chad Deering and Robert Barron for their instruction in mineralogy, petrology, and field geology; Jeremy Shannon for his instruction in structural geology and for making his Field Geophysics class available for conducting a magnetometer survey in our study area; and Aleksey Smirnov for his instruction in geophysics and the use of his lab and personnel for paleomagnetic sampling and analysis. I would also like to thank Graham Hubbell for his assistance conducting field work, presentation preparation, and thin section work. Daniel Lizzardo-McPherson also contributed with data collection in the field and assistance with ArcGIS in the office. Leonid Surovitsky also helped with paleomagnetic sampling. Daniel Trekas analyzed paleomagnetic samples in the lab and helped with the paleomagnetic data collection. I also thank the U.S. Geological Survey for EDMAP funding and the GMES Department at Michigan Technological University for its financial support. Lastly, I would like to thank my wife Jennie Tyrrell for her encouragement and love throughout this process. 


\section{List of abbreviations}

$\begin{array}{ll}\text { DEM } & \text { Digital Elevation Model } \\ \text { DGPS } & \text { Differential Global Positioning System } \\ \text { Ga } & \text { Billion years } \\ \text { GPS } & \text { Global Positioning System } \\ \text { GMES } & \text { Department of Geological and Mining Engineering and Sciences, } \\ & \text { Michigan Technological University } \\ \text { JS } & \text { Jacobsville Sandstone } \\ \text { KF } & \text { Keweenaw Fault } \\ \text { MRS } & \text { Midcontinent Rift System } \\ \text { PLV } & \text { Portage Lake Volcanics } \\ \text { SBAS } & \text { Satellite Based Augmentation Systems } \\ \text { USCG } & \text { United States Coast Guard } \\ \text { USGS } & \text { United States Geological Survey }\end{array}$




\section{Abstract}

The Keweenaw Fault (KF) has been interpreted as a rift-bounding normal fault along the southern margin of the Midcontinent Rift System; later inverted into a reverse fault by a tectonic compression event. The fault trends NNE to NE for most of its trace but curves clockwise to ESE along the Bête Grise Bay area in Michigan's Keweenaw Peninsula. U.S. Geological Survey maps depict the KF along Bête Grise Bay as a continuous thrust that follows a sinuous contact between Portage Lake Volcanics (PLV) and Jacobsville Sandstone (JS). New fieldwork reveals a left-stepping en echelon system of ESE-trending faults connected by ENE trending faults. SE-dipping PLV layers are interpreted as the south flank of an anticlinal structure along the shoreline south of Bare Bluff. Three PLVJS contacts previously mapped as being faulted are now interpreted as unconformities. Fault slip indicators recorded on 34 fault surfaces show that overall movement on the fault system in this area has a ratio of strike slip to dip slip of $2: 1$. Field relationships indicate that PLV units were deformed by faulting and folding prior to JS deposition, with lesser deformation occurring after JS deposition. 


\section{Introduction}

The Keweenaw Fault (KF) has been interpreted as a rift-bounding normal fault along the southern margin of the southwest arm of the Midcontinent Rift System (MRS), which was later inverted into a reverse fault by a tectonic compression event (Cannon, 1994; Hinze and Braile, 1990). The fault trends NNE to NE for most of its trace but curves clockwise to ESE along the Bête Grise Bay area in Michigan's Keweenaw Peninsula (Figure 1). Near Houghton (MI) the fault has inferred dip slip of at least $8 \mathrm{~km}$ (Cannon and Nicholson, 2001; DeGraff et al., 2018).

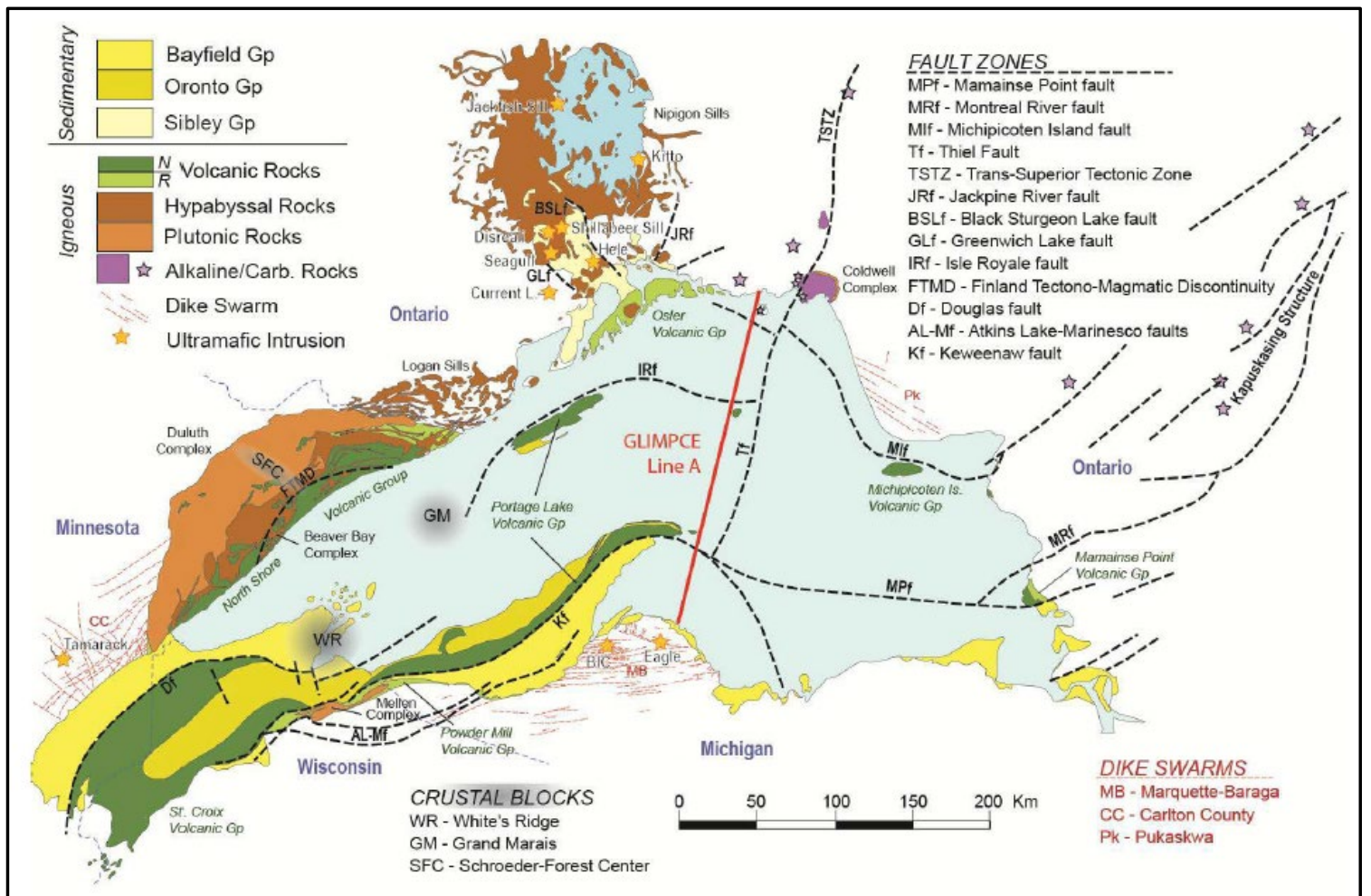

Figure 1. Keweenawan geology of the Midcontinent Rift System in the Lake Superior Basin (Miller and Nicholson, 2013). Credit: Precambrian Research Center Guidebook 13-01, p. 5. 
U.S. Geological Survey (USGS) maps depict the KF along Bête Grise Bay as a continuous thrust that follows a sinuous contact between Portage Lake Volcanics (PLV) and Jacobsville Sandstone (JS). Because the KF is interpreted as a thrust fault along its NNEtrending trace, the aim of this study was to investigate if slip kinematics change as the fault trace curves to the ESE. Therefore, this work addresses movement of the fault by observing, measuring, analyzing, and interpreting kinematic slip indicators along the Bête Gris Bay area of the Keweenaw Peninsula.

During the 2017 and 2018 field seasons, geological and geophysical work was conducted between Bête Grise Bay and Big Bay along the south shore of the Keweenaw Peninsula in Keweenaw County, Michigan (Figure 2). Fieldwork was conducted as part of a USGS Educational Mapping project (EDMAP Award \# G17AC00115; Keweenaw Fault Geometry, Secondary Structures, and Slip Kinematics along the Bête Grise Bay Shoreline), in an effort to map an area approximately 10 square miles in size (Figure 2). A final map and report on this EDMAP project were submitted to the USGS in 2018 (DeGraff et al., 2018). The results of the study reported here focuses on a smaller area around Bare Hill (Figure 3) where specific structural problems were identified for further investigation. 


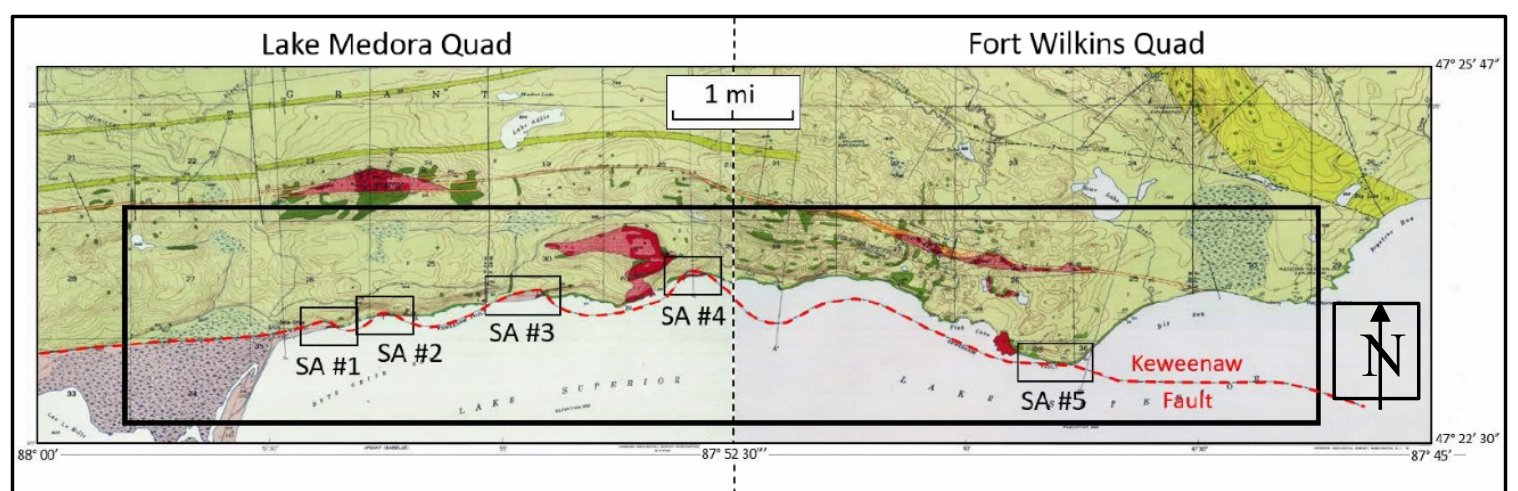

Figure 2. Parts of two USGS geological maps covering the Bête Grise Bay - Big Bay area of the Keweenaw Peninsula, Michigan (Cornwall, 1954; Cornwall, 1955). Credit: U.S. Geological Survey, Department of the Interior/USGS.

The study area, centered on Bare Hill along Bête Grise Bay, extends west to Bear Creek, east to the old Smith Fishery property, north to the Bohemia Conglomerate, and south into the near offshore (Figure 3). The area is structurally significant because well exposed contacts between the PLV and the JS along the shoreline provide an opportunity to investigate the geometry, slip kinematics, and general nature of the Keweenaw Fault system near its easternmost onshore location. This report summarizes the findings of a detailed structural study that includes two such areas labeled SA \#3 and SA \#4 (Figures. 2, 3). 


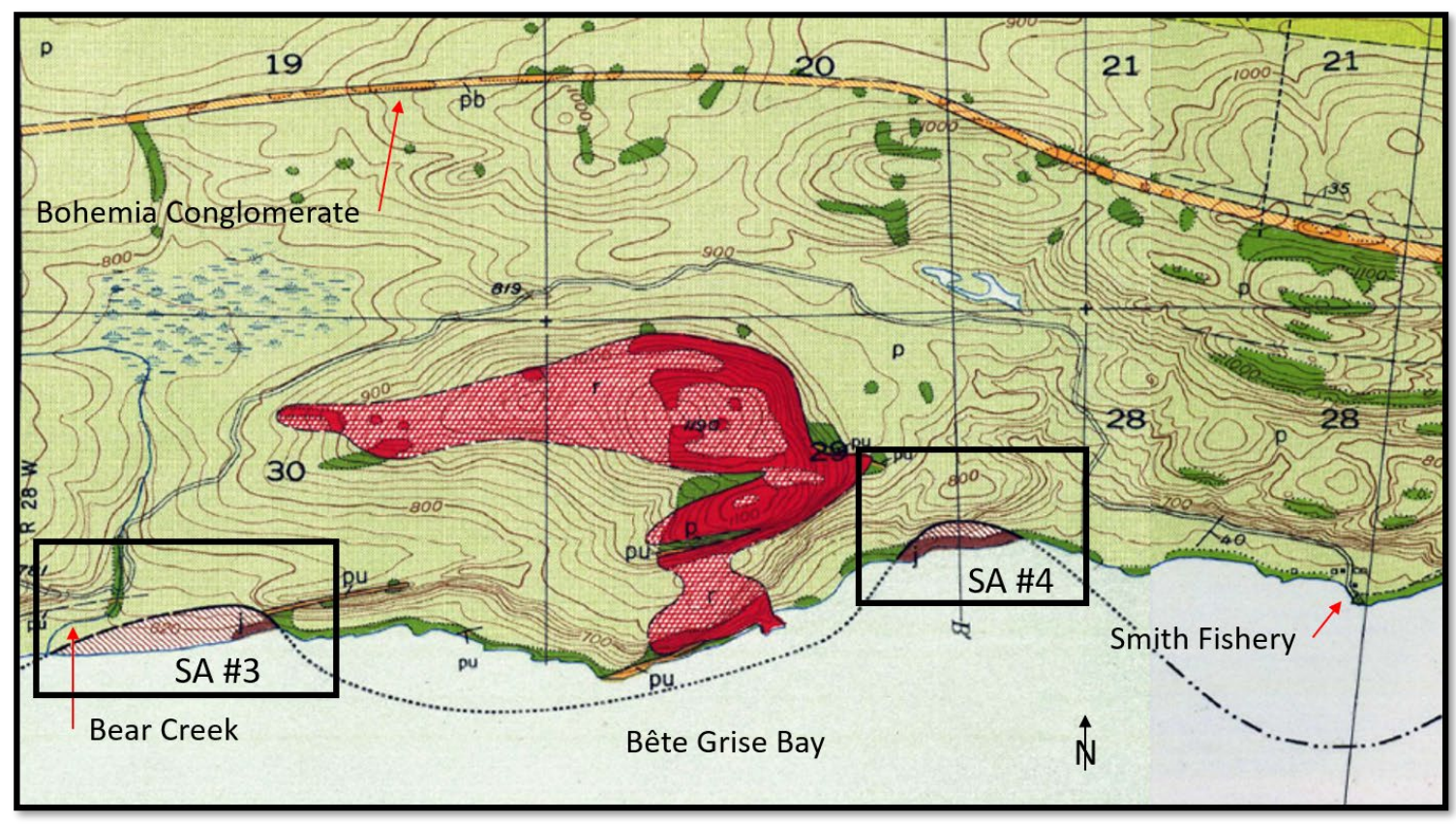

Figure 3. U.S.G.S. geological map of the study area (Cornwall, 1954; Cornwall, 1955). Note the sinuous path of the KF trace denoted as a black solid, dashed, and dotted line. Rock units: basalt - green, rhyolite - red, conglomerate - orange, Jacobsville Sandstone - maroon. Credit: U.S. Geological Survey, Department of the Interior/USGS.

The main purpose of this M.S. project was to determine the geometric and slip characteristics of the Keweenaw Fault near the tip of the Keweenaw Peninsula. Additional goals were to identify and interpret deformation of rock units adjacent to fault segments and infer the timing of fault slip. The broader EDMAP project provided a detailed map that better constrains the geometry of the fault system and adjacent deformed rock units. The EDMAP fieldwork revealed a left-stepping en echelon system of ESE-trending faults connected by ENE-trending faults. SE-dipping PLV layers were interpreted as part of an anticlinal structure along the shoreline south of Bare Bluff. Three PLV-JS contacts were interpreted as unconformities (DeGraff, 2018). Work reported for this M.S. project has further refined the EDMAP results and additionally has measured and analyzed fault slip 
indicators to provide an updated interpretation of the sense and direction of movement along the fault. 


\section{Previous Work}

Between the 1840 s and 1880 s, geologists investigating the copper-rich Keweenaw Peninsula debated whether the contact between basaltic lava flows to the northwest (PLV) and sandstone strata to the southeast (JS) was a fault contact or normal stratigraphic succession (Foster and Whitney, 1849-1850; Irving and Chamberlin, 1885; Jackson, 18491850). This debate effectively ended when Irving and Chamberlin (1885) published their observations and interpretation of this region, concluding that the PLV-JS contact was a major fault. They based this conclusion on: (1) diverging dips of the PLV (NNW) and the JS (SSE to horizontal); (2) presence of fault gouge along the contact; and (3) lithologic differences between the JS and sandstone found west of the Keweenaw Peninsula, which they regarded as part of a conformable sequence above the PLV. Ever since the work of Irving and Chamberlin (1885) PLV-JS contacts along the Keweenaw Peninsula have been mapped as a fault. In the Bête Grise Bay area, this led to interpretation of a sinuous fault trace that connects each exposed contact between PLV on the north and JS on the south (Figure 2; Cornwall, 1954; Cornwall, 1955).

Early geological work also suggested an overall anticlinal structure for the Keweenaw Peninsula (Figure 4; Foster and Whitney, 1850). Foster and Whitney reported southward dips of PLV and JS strata along Bête Grise Bay in a map and cross section (Foster and Whitney, 1951). Irving and Chamberlin (1885) considered Foster and Whitney's anticline interpretation but found no southeast dips within the PLV on the south side of the peninsula. Although Cornwall shows one southward dip in PLV strata along Bête Grise 
Bay on his Fort Wilkins Quadrangle map (Cornwall 1955), he did not incorporate this orientation into any cross sections.

\section{Early Anticlinal Interpretation}

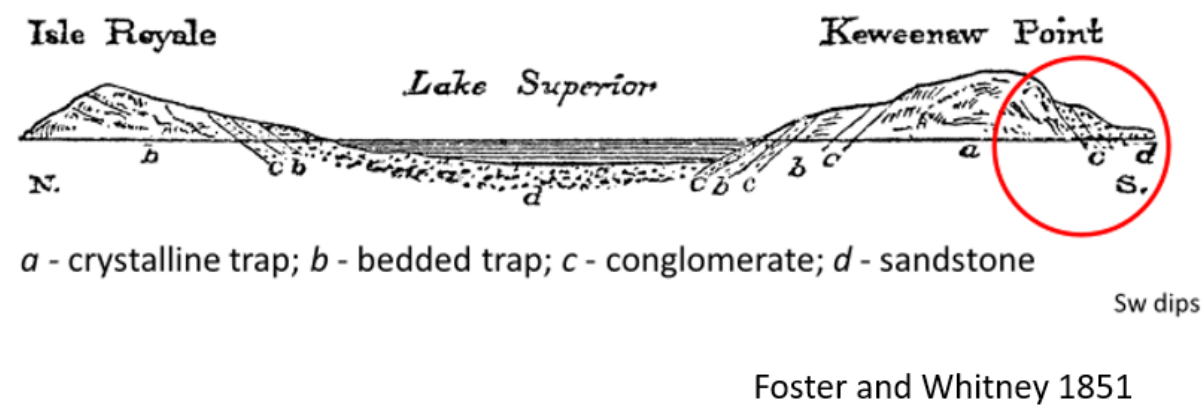

Not to scale.

Figure 4. Anticlinal structure of the Keweenaw Peninsula as interpreted by Foster and Whitney (1851). Red circle highlights their interpretation of SW dips on the south side of the peninsula. Credit: U.S. Geological Survey, Department of the Interior/USGS.

It has been proposed that significant movement along the KF probably occurred before JS deposition, with lesser movement occurring later (Irving and Chamberlin, 1885; Cannon and Nicholson, 2001). Wider zones of brecciation in the PLV, fault bounded lozenges in the PLV, and significant alteration in the PLV, all indicated that the PLV have undergone more extreme and earlier deformation than the JS. Cornwall (1954) observed steeply dipping JS beds along the KF and horizontal beds a short distance from the fault clearly demonstrate the later fault movement (Figure 5). 


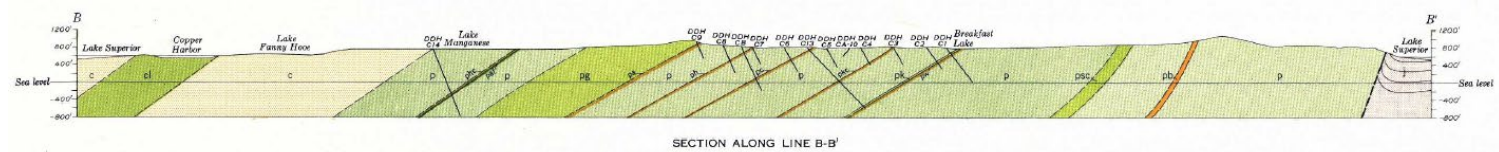

Figure 5. Cross section of thrust fault across Keweenaw Peninsula, Lake Medora Quadrangle, Section B B', Cornwall (1954). See Figure 3 for location. Note the more steeply dipping beds of JS closer to the fault. Credit: U.S. Geological Survey, Department of the Interior/USGS.

This study focused on addressing the nature of the contact between the PLV and JS, analyzing kinematic indicators to determine sense and direction of fault movement, and examining the structural deformation to re-evaluate the idea of an anticlinal structure. 


\section{Methods and Data}

\subsection{Data Acquisition Strategy}

Prior to initiating field work, preparatory work included a literature review to understand previous interpretations of the area. Google Earth images were studied to identify possible exposed outcrops and the fault trace in offshore areas. The field phase of the project focused on visiting sites previously mapped as fault contacts to measure fault-slip indicators such as slickenlines and mineralization. Identifying and mapping interflow sedimentary units was critical to better understand their structural orientation and lateral correlation. Because orientation is critical to interpretation of structural deformation, paleomagnetic samples were collected to supplement data on stratal geometry.

As part of the broader EDMAP project, magnetometer data was collected to constrain the fault location in areas covered in overburden. While useful elsewhere, these data were evaluated but determined to be not as useful for the area described here.

\subsection{Field Geological Mapping}

Initial mapping under the EDMAP project focused on five areas along the shoreline where well exposed PLV-JS contacts had been identified as a single fault in the past (Figure 2). Observations at each field station included a site description, nature of the exposure, rock types and characteristics, nature of any contacts, presence of fractures, and general orientation of units. When possible, a Brunton International Transit was used to measure strike and dip of surfaces, and plunge and bearing or apparent rake of lineations. Sense of 
slip was determined by examination of the slickenfiber steps, and qualitatively categorized as low, medium or high confidence.

During the summers of 2017 and 2018, measurements and observations were recorded at over 1000 outcrops within the EDMAP study area. Hand samples were collected and described for color, texture, and mineralogy to identify rock types and to correlate units within the study area. Slickenlines and oriented mineral fabric were measured at 34 outcrops.

Unit contacts were described and identified as conformable, unconformable, fault, or bedding. Conformable stratigraphic contacts had no discernable difference in stratal orientation, whereas unconformable contacts had divergent strikes and dips of the units and, in some cases, paleosols were present between the units. Fault contacts had zones of brecciation, gouge, or stratal deformation, and surface markings such as slickenlines or a mineral fabric. Basalt exposures were interpreted as flow top, bottom, or interior regions based on size and shape of amygdules and groundmass texture. Navigation was conducted with paper and digital USGS bedrock geology maps of the area. Georegistered digital maps loaded onto an Algiz 7x tablet with GPS capability allowed for location of previously mapped outcrops. Horizontal and vertical positions were determined with submeter precision using Trimble DGPS units most of the time, but conventional GPS units were also used in terrain where Trimble units were not able to receive an SBAS or USCG signal for submeter precision (Table 1). 


\section{Table 1. Equipment Used}

\begin{tabular}{|l|l|l|l|}
\hline Manufacturer / & Description & Measurement & Accuracy \\
\hline Trimble / Geo7x & DGPS w/ SBAS correction & position & $\leq 1 \mathrm{~m}$ \\
\hline Trimble / GPS & DGPS w/ USCG correction & position & $\leq 1 \mathrm{~m}$ \\
\hline Pathfinder Pro XR & & position & $5-10 \mathrm{~m}$ \\
\hline Garmin / Rino & GPS without correction & Moving map & \\
\hline Handheld Algiz 7x & Tablet computer & GPS & field \\
\hline A8XV1-10VZ01 & & meter \\
\hline Geometrics / Unimag & proton-precession & magnetometer & mT \\
\hline II G-846 & & fietic & \\
\hline
\end{tabular}

\subsection{Field Geophysical Work}

Magnetometer data were collected east of Bare Bluff to constrain fault locations in areas with limited outcrops. Students from the 2018 Field Geophysics course conducted much of the survey during the summer. Survey lines and measurement stations were set up prior 
to the magnetometer survey using a Brunton International Transit and measuring tape (chain), with emphasis on the horizontal orientation of the "chain" in areas of steep topography. Station spacing was $50 \mathrm{ft}$ and line spacing was at $200 \mathrm{ft}$ intervals. Differential GPS positions were collected at key locations in order to accurately locate the survey grid on the final maps. A proton-precession magnetometer was used to measure the total magnetic field strength arising from rocks straddling the Keweenaw Fault. Recordings at base stations were taken at time intervals of less than one hour for drift error corrections.

Paleomagnetic samples were taken to verify structural rotation of PLV units within the study area. Samples were collected with a portable, gas powered, diamond tipped drill bit and the orientations were measured with a sun compass according to standard methods (Trekas, 2019). These data were collected and initially analyzed by our field team, and subsequently incorporated into a parallel M.S. project conducted by Trekas (2019). His M.S. thesis should be consulted for details of methodology and results. 


\section{Results}

Geological data described above were loaded into the ArcGIS program ArcMAP and displayed at 1:40,000 scale with previously digitized information from USGS geologic maps. The new geologic data were used to confirm or modify geologic boundaries and features from previous maps and better constrain lithologic contacts, structural orientation of units, fault segment traces, and unconformities (Figure 6; DeGraff, 2018). Over the broader EDMAP area, the map pattern reveals an en echelon system of ESE-oriented leftstepping fault segments connected by ENE-trending faults. This fault pattern and associated folding are described and analyzed below for the smaller focus area discussed in this report.

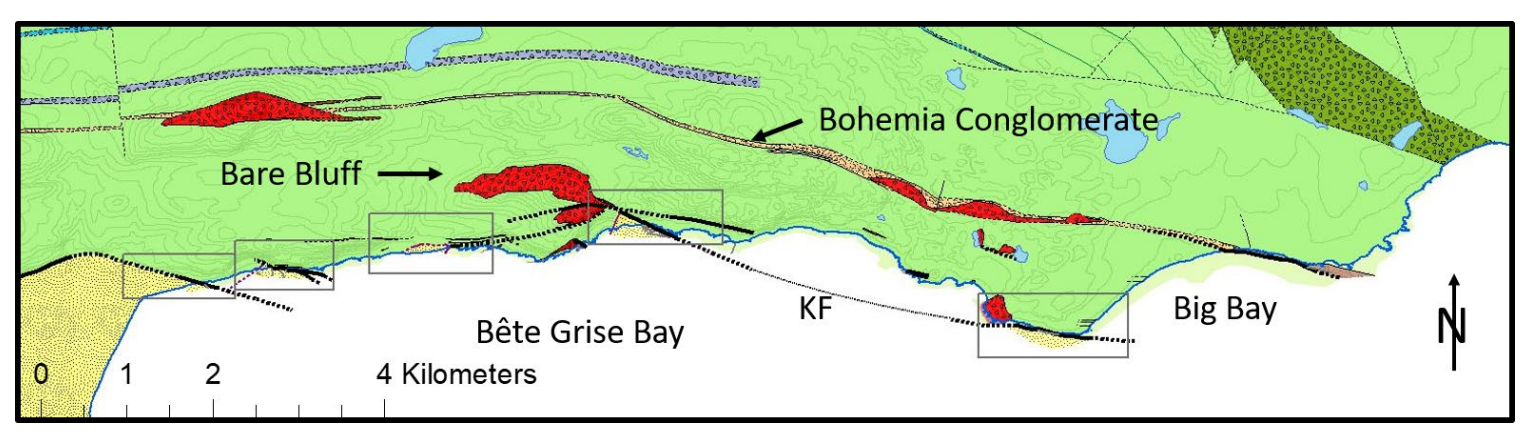

Figure 6. Keweenaw Fault system along Bête Grise Bay area of Keweenaw Peninsula. Faults denoted with bold black lines, bold dotted lines. Rock unit colors: basalt - green, rhyolite - red, conglomerate orange and brown, JS - yellow (DeGraff, 2018). Credit: U.S. Geological Survey, Department of the Interior/USGS.

\subsection{Nature of the PLV-JS Contact}

Field observations reveal that the PLV-JS contact, previously mapped as a continuous fault in this area, actually consists of both faulted and unconformable contacts (Figure 7). 


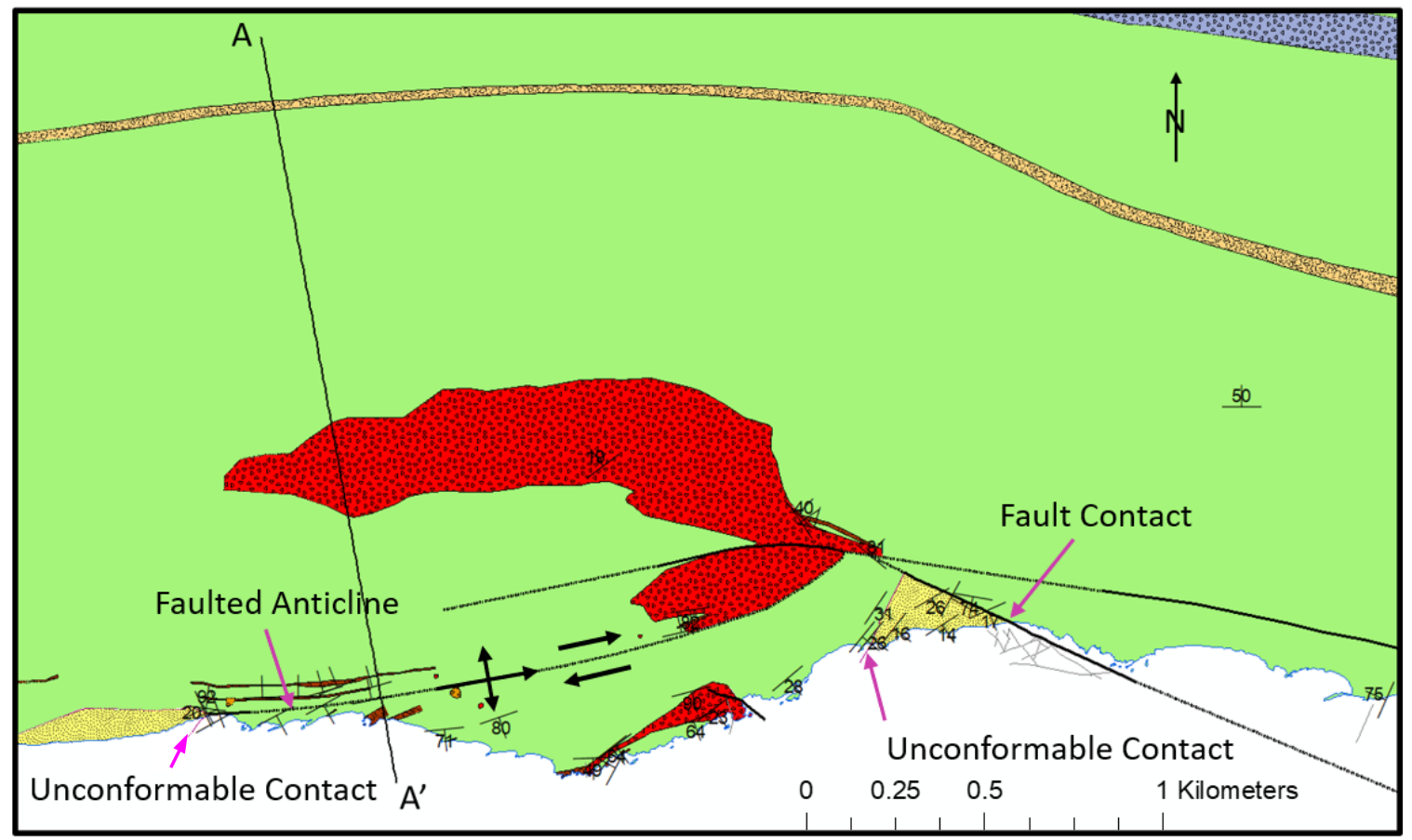

Figure 7. New fault pattern from analysis of mapping data and interpretation of variation in orientation of bedding planes. Faulted anticline lies southwest of Bare Bluff. Rock unit colors: basalt - green, rhyolite red, conglomerate - light and dark brown, JS - yellow.

Mapping of Subarea \#4 (Figure 7, eastern JS outcrop) has revealed that the Jacobsville Sandstone is bounded by a fault to the north and an unconformity to the west. The fault contact $\left(\mathrm{Az}=297^{\circ}, \mathrm{D}=74^{\circ} \mathrm{N}\right)$ is a 14 feet wide zone of brecciated PLV basalt to the north, and a $10 \mathrm{~cm}$ zone of brecciated JS to the south (Figure 8). Fault gouge is present between PLV and JS to the south. The JS bedding is subvertical at the fault but becomes subhorizontal within 1-2 meters to the south. 


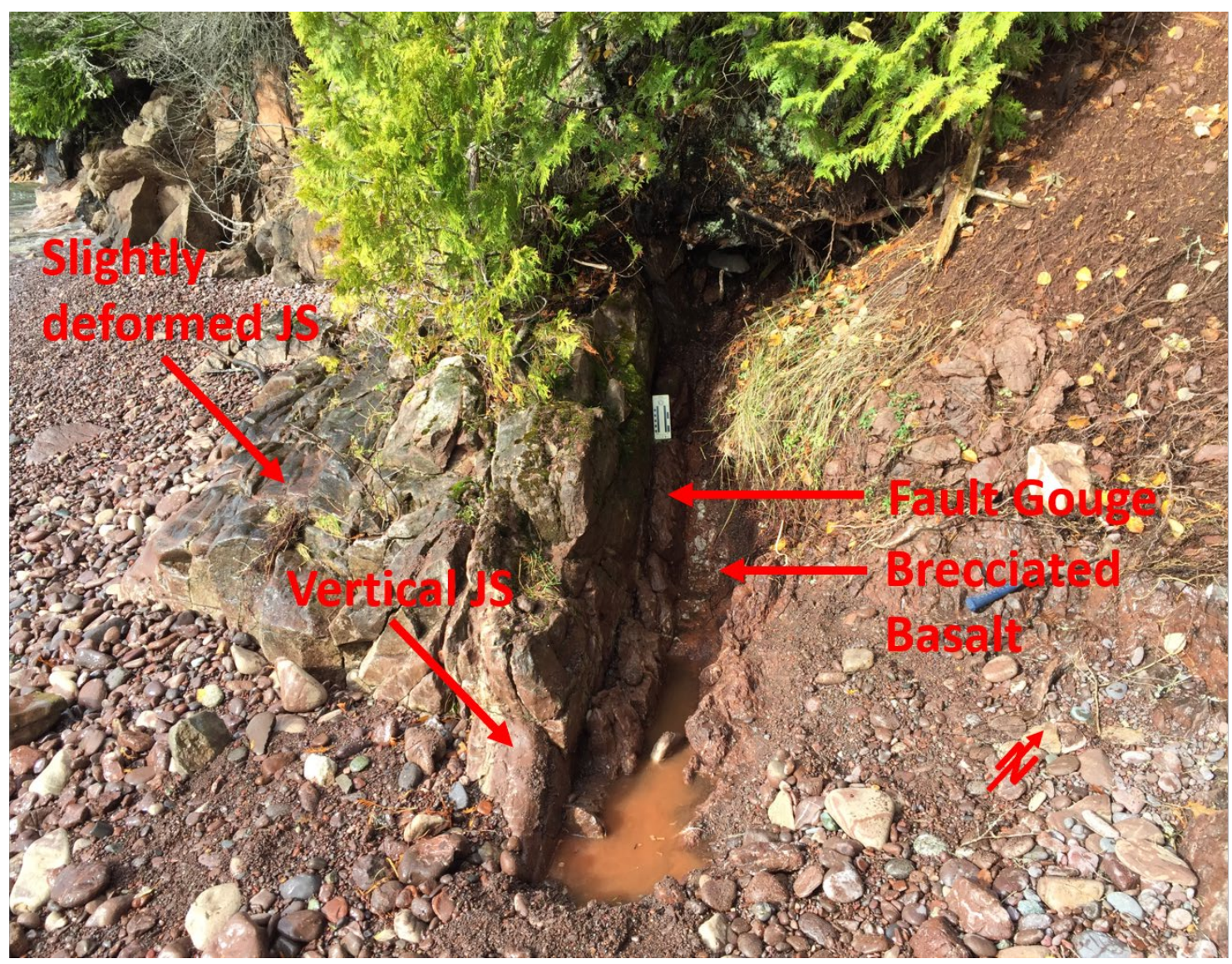

Figure 8. Faulted contact between PLV (right) and JS (left). Look direction is westward and subparallel to the fault. Deformation as defined by brecciation and veining is more intense in PLV than in JS.

The unconformable contact at the west side of Subarea \#4 (Figure 9,) exhibits basalt dipping $\sim 38^{\circ} \mathrm{SE}$ overlain unconformably by JS dipping $\sim 25^{\circ} \mathrm{SE}$. There was no evidence of brecciated basalt or fault slip indicators along this contact. Since the dips of the PLV and JS differ and a paleosol exists between the two. We conclude that this is an unconformable contact. 


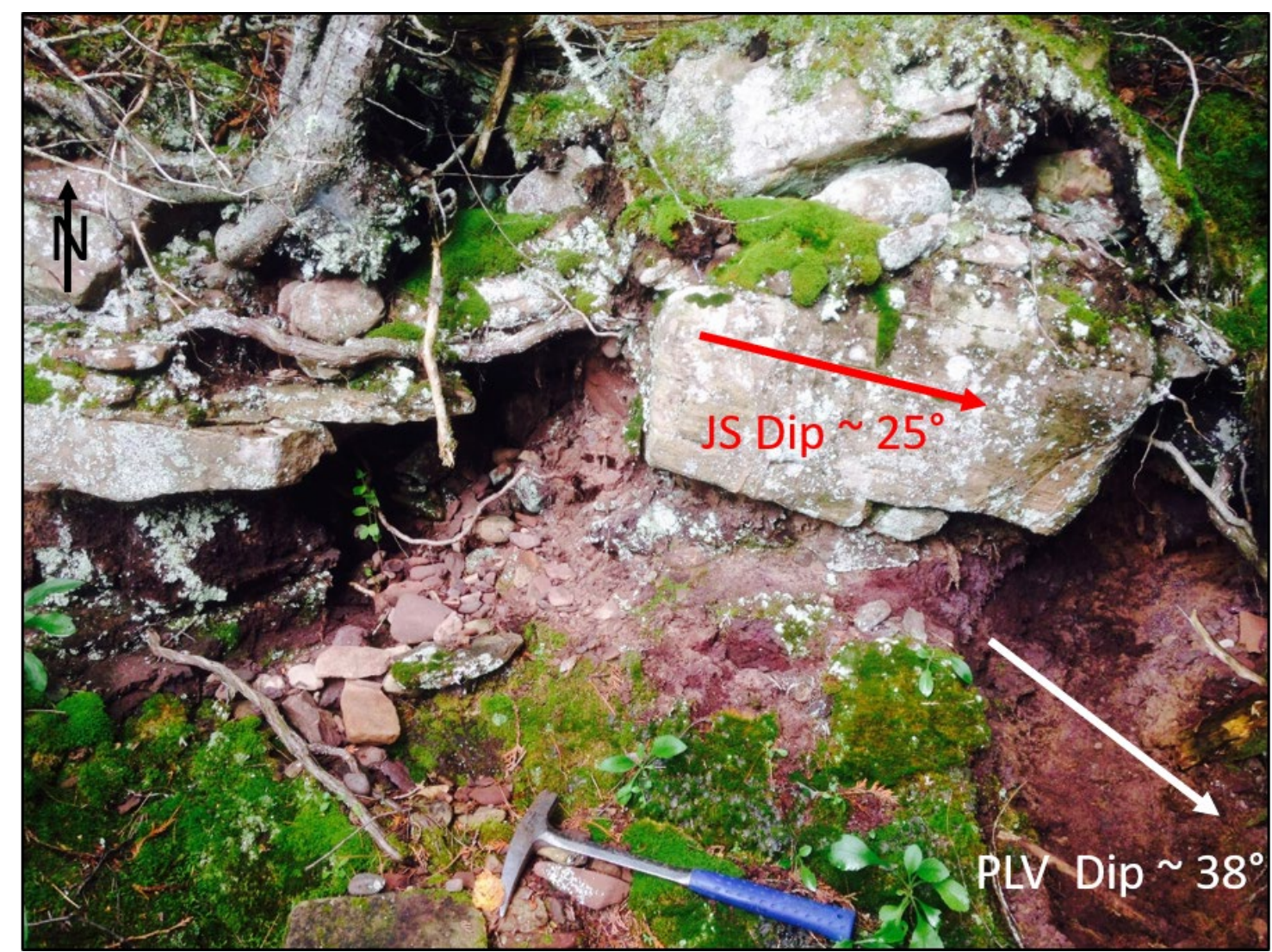

Figure 9. Unconformity at west side of subarea \#4. The basalt dips $\sim 38^{\circ} \mathrm{SE}$ and $\mathrm{JS} \operatorname{dips} \sim 25^{\circ} \mathrm{SE}$.

Another unconformity between PLV and JS strata occurs at the east side of Subarea \#3

(Figure 7) along the shoreline. Here basalt strata strike ENE and dip up to $83^{\circ} \mathrm{SSE}$.

Subhorizontal JS strata overlie the basalt offshore to the south, and on the shoreline overlie

a fault zone $\left(\mathrm{Az}=265^{\circ}, \mathrm{D}=74^{\circ} \mathrm{N}\right)$ of brecciated and sheared basalt. The unconformable JS is slightly deformed above the fault zone and appears to become horizontal in an offshore direction (Figure 10). 


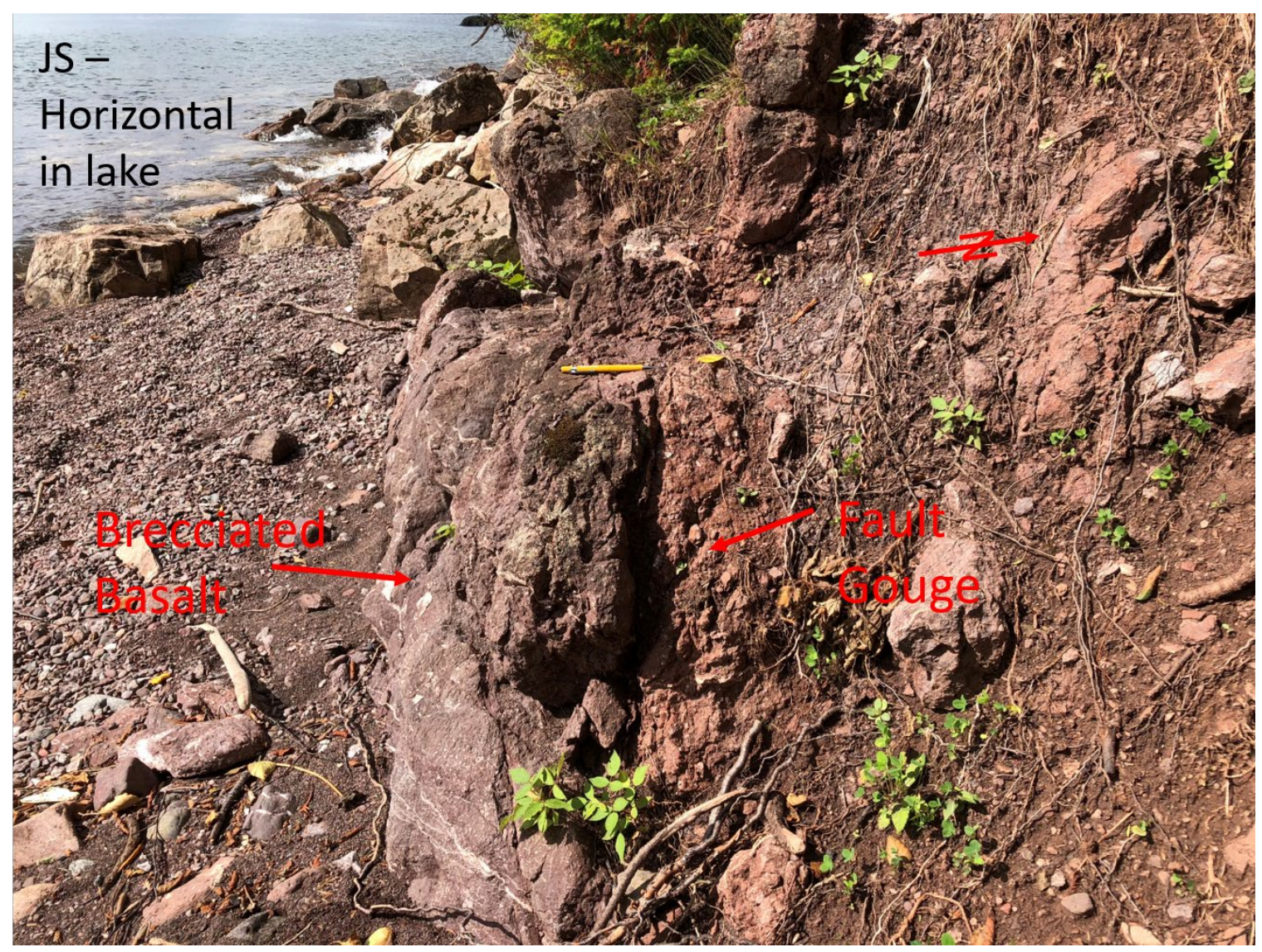

Figure 10. East side of SA \#3 showing shoreline unconformity at PLV - JS contact. Horizontal JS overlies basalt north and south of a fault zone with anastomosing shear bands cutting a basalt breccia. Look direction is westward. See Figure 7 for location.

The redefinition of Keweenaw Fault geometry in this area, based on the recognition of both faulted and unconformable PLV - JS contacts, changes the paradigm for the fault and motivated a study of kinematic slip indicators on fault surfaces.

\subsection{Fault System Trace and Analysis}

Rake of lineations measured on a fault surface defines the slip direction. Rakes of lineations within the study area were plotted using the Stereonet program (Allmendinger, 2013), 
which also produces radial plots. The radial histogram (Figure 11) reveals that the mode of rake lineations is between $20^{\circ}$ and $30^{\circ}$ from the strike line of measured faults, and that the arithmetic average is generally west $26^{\circ}$. This average rake direction corresponds to a 2:1 ratio of strike slip to dip slip.

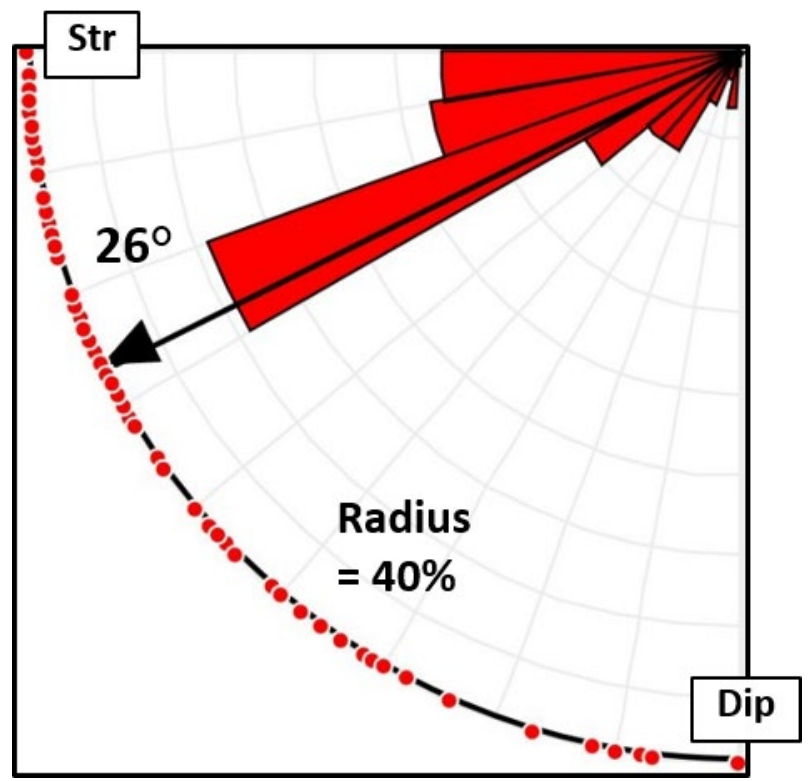

Figure 11. Radial histogram of rakes of fault lineations define the fault as predominantly strike-slip. Black arrow denotes arithmetic mean of data.

Strike and dip of fault surfaces, plunge and bearing of rake lineations, and sense of slip were plotted with FaultKin; a freeware application for analyzing fault-slip data (Allmendinger, 2012). The fault-slip analysis was used in an attempt to find the principal strain axes and predicted fault-slip behavior that best matches field observations in a leastsquares sense. Figure 12 shows fault planes used in the analysis and the three computed principal strain axes. The resulting strain axes reveal a maximum shortening direction with 
azimuth $297^{\circ}$. When this shortening direction is superimposed on the dominant fault trend in the area, resulting fault movement would be oblique with dominant right-lateral strike slip and lesser reverse slip with north side up.

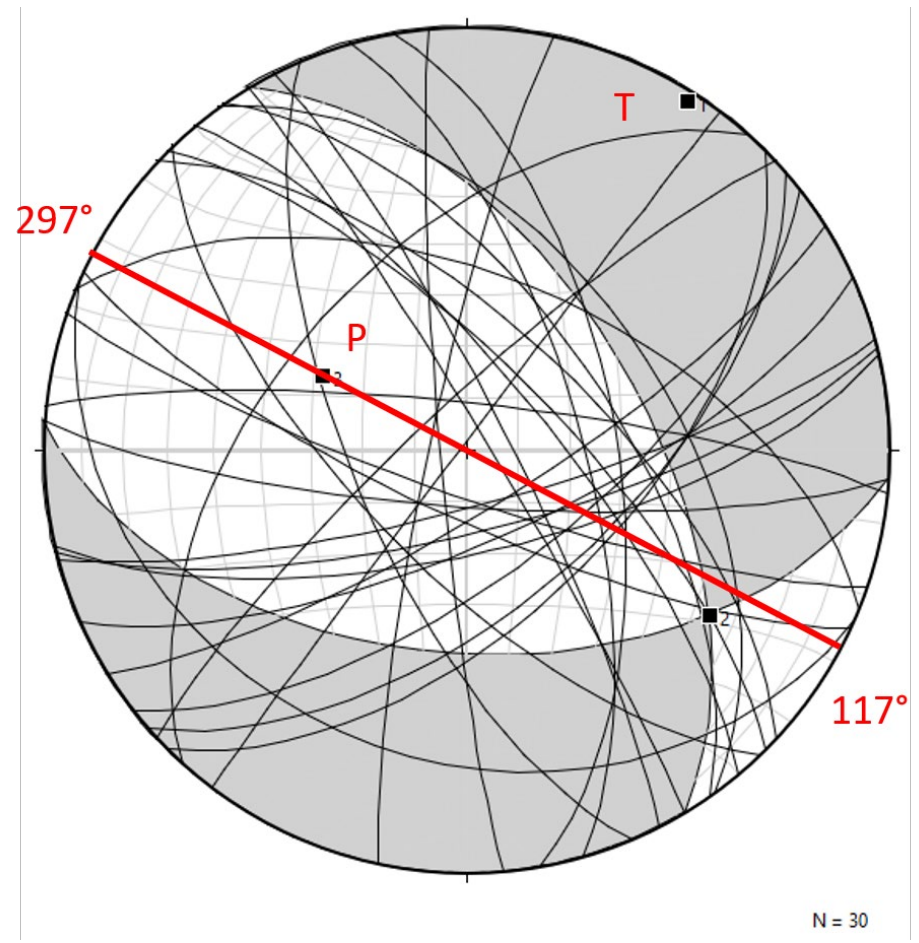

Figure 12. FaultKin plot using fault planes, rake lineations, and sense of slip to compute three principal axes of deformation. The principal shortening direction, given by axis \#3 and projected onto a horizontal plane, is along a line with azimuth $117^{\circ}-297^{\circ}$.

\subsection{Anticlinal Structure}

Mapping and measurements of stratal orientations define an anticlinal structure south of Bare Bluff that is cut by an ENE-trending fault (Figure 7). On the north flank of this anticline, PLV basalts and conglomerates on average strike $260^{\circ}$ and dip $68^{\circ} \mathrm{N}$. A zone of brecciated basalt with anastomosing seams, striking $265^{\circ}$ and dipping $74^{\circ} \mathrm{N}$, bounds these 
units on the south. South of the fault zone, PLV basalts and conglomerates strike $062^{\circ}$ and $\operatorname{dip} 83^{\circ} \mathrm{SE}$.

Poles to bedding planes across this structure, plotted on an equal area stereonet (Figure 13), define an asymmetric fold with an interlimb angle of $\sim 30^{\circ}$. Pole $\# 3$ represents the fold axis with a plunge of $10^{\circ}$ at a bearing of $076^{\circ}$. The girdle defined by these poles and represented by colored contours is fit by a curved black line that represents a plane perpendicular to the fold axis. We interpret that the anticline was formed by the dextral shear and shortening identified along the faulted surfaces in this area.

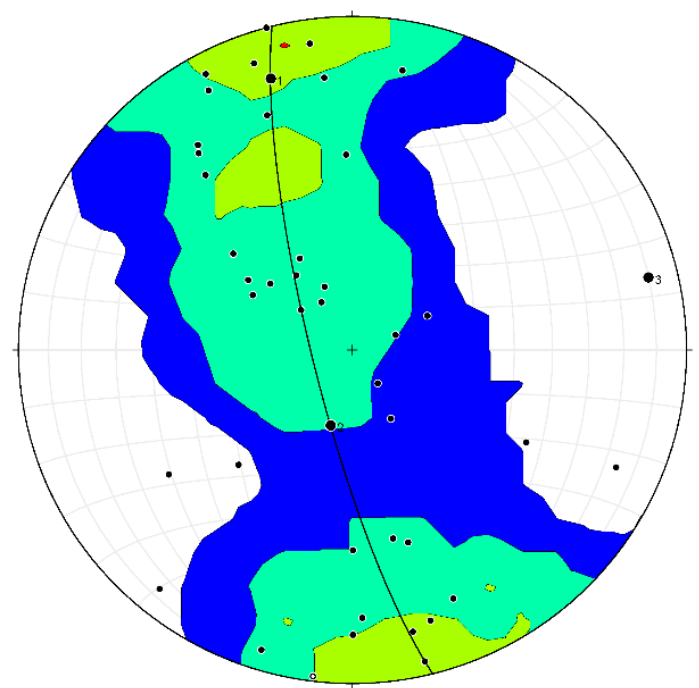

Figure 13. Poles of bedding planes (small dots) in the fold area southwest of Bare Bluff (Figure 7 for location). Pole \#3 is the fold axis of the anticline. Stereonet, 2011-2016.

Cross section A-A' (Figure 14) was generated from DEM data input into ArcMAP 6.1, mapped layer contacts in the field, and measurements of bedding orientation. The best strike and dip measurements were collected to the south of Bare Hill. Since quality strike 
and dip measurements were lacking to the north of the faulted anticline, several assumptions were used in creating this cross-section. First, rhyolite is shown as a conformable member of the PLV at the base of the anticline. Second, a vertical fault cuts the rhyolite body at Bare Hill. Third, horizontal bedding of the PLV to the south of Bare Hill. Fourth, all PLV units to the north of Bare Hill are constrained by the mapped Bohemia Conglomerate to the north, and dip to the north

Analysis of map data and bedding poles on a stereonet has revealed an asymmetric fold located south of the main rhyolite body (Figures 7, 13). Layering in the north limb of the anticline - also the hanging wall of the fault - is parallel to fault strike, whereas layering in the south limb (foot wall) is oblique to fault strike. I identified a vertical dextral fault cutting the rhyolite that is projected through the cross section to the north of the asymmetric fold. 


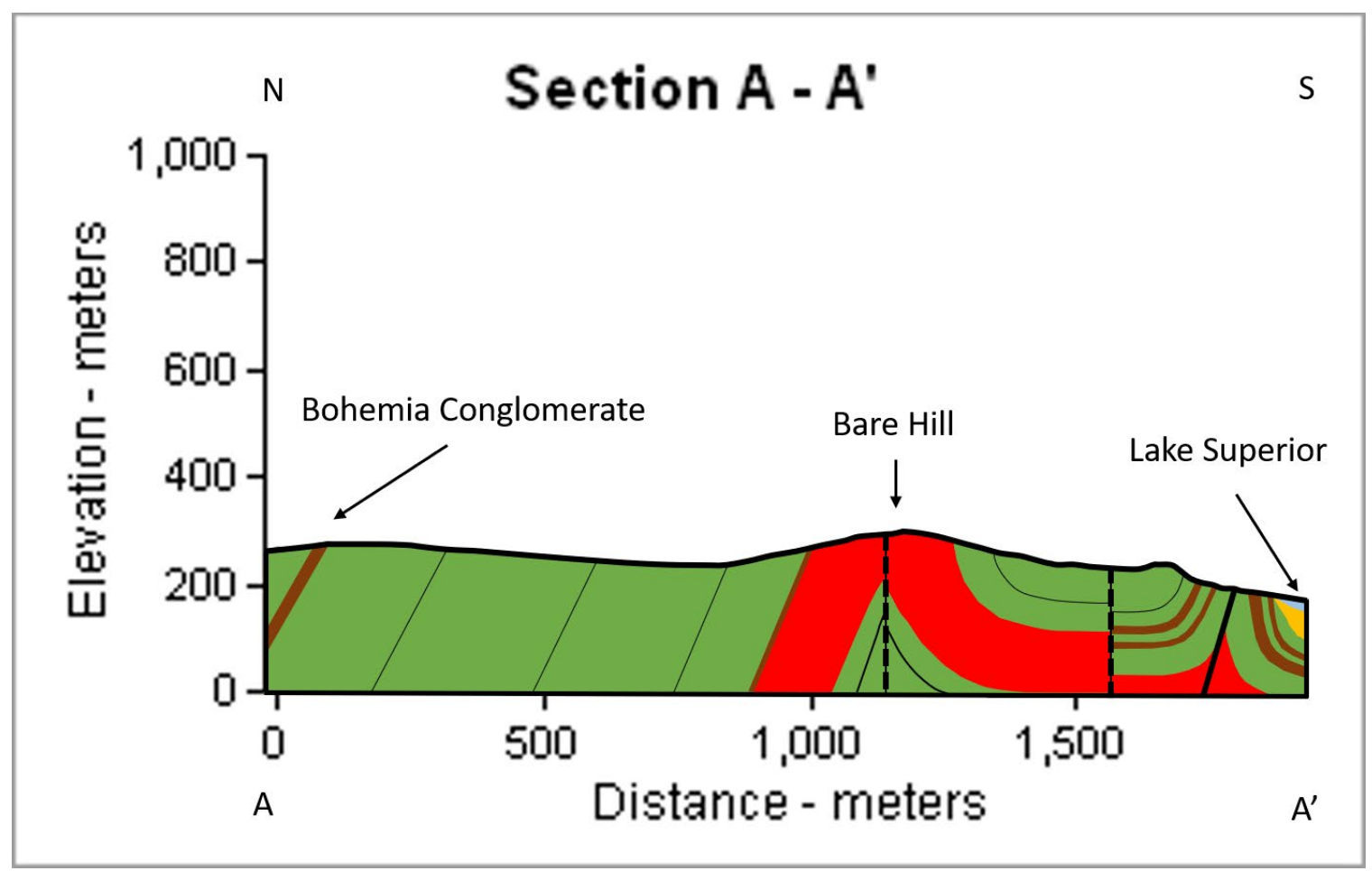

Figure 14. Cross section through the Bare Hill area constructed perpendicular to structural trend. (Figure 11 for location). USGS strike and dips constrain north side of the section from the Bohemia conglomerate south to the rhyolite body. Thick solid black line denotes mapped fault, thick dashed black lines denote interpreted faults, thin black lines are form lines of bedding within basalt. Rock unit colors: basalt - green, rhyolite red, conglomerate - brown, sandstone - yellow, Lake Superior - light blue at far right.

\subsection{Timing of fault movement}

I conclude that substantial movement of some or all fault segments occurred before JS deposition. Evidence for this interpretation includes the following: 1) wide zones of highly brecciated basalt, 2) fault-bounded lozenges of basalt, 3) significant alteration of basalt locally to saprolite, and 4) subvertical PLV units. A lesser amount of fault movement occurred after JS deposition based on its layers being slightly deformed near the fault contact and the unconformable relationships at the east side of SA \#3 (Figure 10). Sandstone dike intrusion cutting the PLV in the hanging wall of a fault segment east of the 
study area (Figure 2, SA\#5) suggests that the JS was not fully lithified as it was injected into the PLV during the later episode of faulting.

\subsection{Geochemical Analysis}

Three samples of PLV with SE dips were sent to the USGS for analysis. The origin of mafic units dipping to the south are important to the interpretation of structural deformation in the study area. Therefore, we decided to compare the geochemistry of samples from the study area with known PLV samples from other locations. The new geochemical analyses strongly suggest that samples of layers dipping SE at the southern edge of the study area are part of the PLV section (Figure 7). All three samples (Figure 15, green triangles) are compositionally similar to PLV from other locations (Figure 15, green outline).

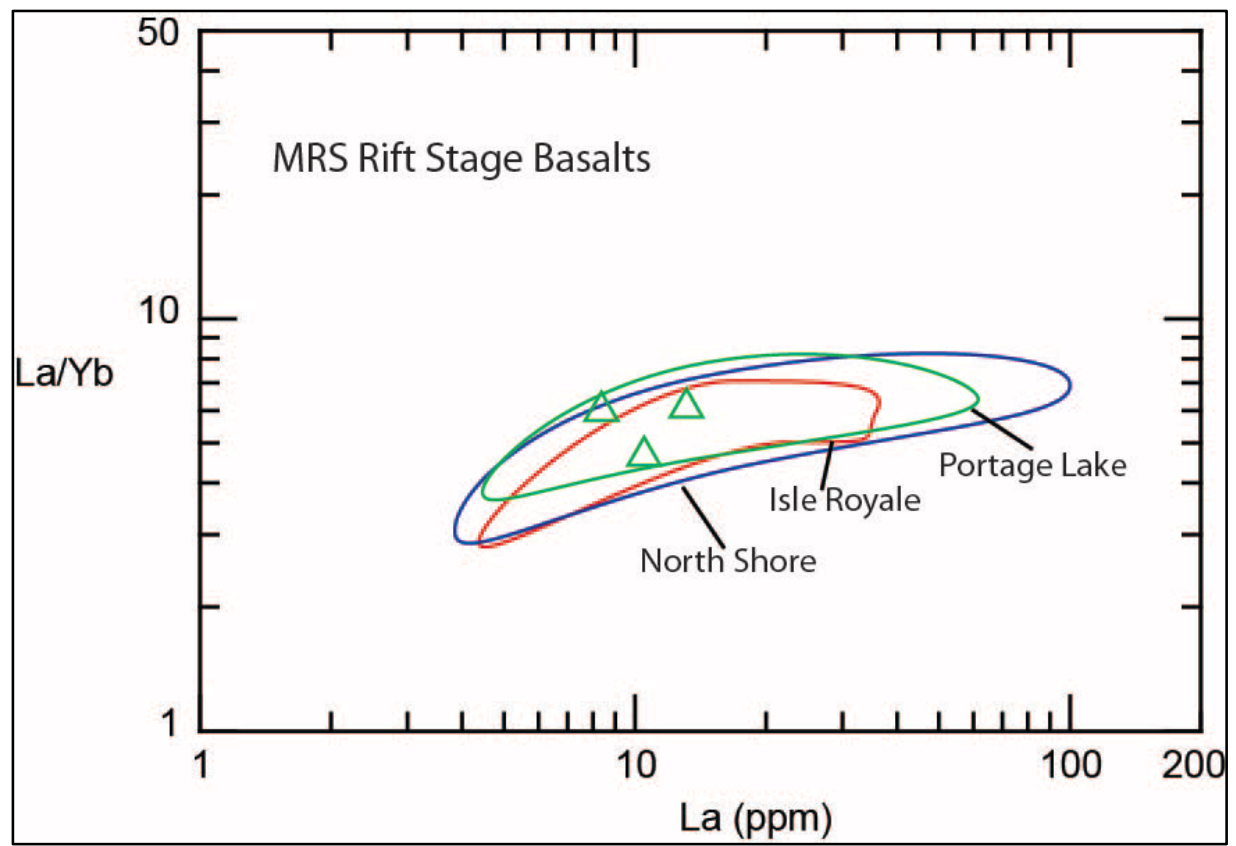

Figure 15. Rare-earth element plot. (Schultz, K., 2018). Green triangles represent the plot of our samples that are compositionally similar PLV from other areas. Credit: U.S. Geological Survey, Department of the Interior/USGS. 


\section{Discussion}

Published maps (Cornwall, 1954; Cornwall, 1955; Cannon and Nicholson, 2001) show the Keweenaw Fault as a sinuous trace along the Bête Grise Bay shoreline of the Keweenaw Peninsula. This interpretation appears to have resulted from accepting every PLV - JS contact as a faulted contact based on the seminal work of Irving and Chamberlin (1885). Research reported here, based on detailed mapping at each PLV - JS contact along Bête Grise Bay, reveals that some PLV-JS contacts previously mapped as faults are in fact unconformities. Observations in SA \#2, SA \#3, and SA \#4 provide evidence for unconformable contacts between the PLV and JS, which thus separate the once continuous fault trace into a segmented system. The resulting map shows a system of ESE-trending fault splays with ENE-connecting faults. Other geologists had noted one of the ENEtrending faults (Papadakis and Raza, 1954) and SE dip of the PLV (Cornwall, 1955), but this information was largely omitted from USGS maps and cross sections.

The same published maps show N-dipping PLV layers in the study area, and accompanying reports interpret the southern edge of the PLV as a Proterozoic escarpment. According to Irving and Chamberlin's cross section, the PLV series with NW dip continues under the JS. This was a logical conclusion considering that they were unaware of SE dips in the PLV along the south shore of the peninsula. However, in this study I have identified a tightly folded and faulted anticline southwest of Bare Bluff (Figure 7). This discovery changes the interpretation of the fault geometry along this section of the KF (Figure 14). Because this interpretation is contingent on identifying the stratigraphic up direction, which 
can be difficult in steeply dipping lava flows, paleomagnetic samples were taken on both sides of the fold to further test this interpretation. Preliminary analysis of paleomagnetic samples from south of Bare Bluff (Trekas, 2019) confirms the presence of an anticline in this area. Analysis of additional samples from the area is ongoing and, when completed, will provide further testing of the structural model presented here. 


\section{Conclusion}

The results of this study redefine the contact between the PLV - JS as a fault contact in some places and an unconformable contact in others. Fine-scale outcrop mapping with submeter accuracy allowed creation of a new map with much improved geometry of contacts between rock units. The map reveals a faulted anticline southwest of Bare Bluff and a left-stepping ESE oriented en echelon system of faults connected by ENE fault segments. Measured fault-slip indicators indicate a 2:1 ratio of strike-slip to dip-slip on the fault system in the area. Further analysis of the dataset from the magnetometer survey is needed to identify other faults in the area and better constrain mapped faults. Detailed bathymetric work may elucidate the trace of the fault offshore. Seismic refraction and reflection work may further improve our understanding of the orientation of the various units. Cross section construction and analysis using Move software would be useful in

confirming or modifying the cross-section presented here and for more rapidly and accurately generating new cross sections. 


\section{References Cited}

Allmendinger, R. W., Cardozo, N., and Fisher, D., 2012, Structural geology algorithms: Vectors and tensors in structural geology: Cambridge University Press, p. 302.

Allmendinger, R. W., Cardozo, N. C., and Fisher, D., 2013, Structural Geology Algorithms: Vectors \& Tensors: Cambridge, England, Cambridge University Press, p. 289.

Cannon, W.F., 1994, Closing of the Midcontinent rift—A far-field effect of Grenvillian compression: Geology 22, p. 155-158.

Cannon, W.F., Peterman, Z.E., and Sims, P.K. 1993, Crustal scale thrusting and origin of the Montreal River monocline - a 35-km-thick cross section of the Midcontinent rift in northern Michigan and Wisconsin: Tectonics, v. 12, p. 728 - 744.

Cannon, W.F. and Nicholson, S.W., 2001, Geologic Map of the Keweenaw Peninsula and Adjacent Area, Michigan: United States Geological Survey, Map I-2696, Scale= 1:100,000.

Cornwall, H. R., 1954, Bedrock geology of the Lake Medora quadrangle, Michigan: USGS Geologic Quadrangle Map GQ-52, scale 1:24,000.

Cornwall, H.R., 1955, Bedrock geology of the Fort Wilkins quadrangle, Michigan: USGS Geologic Quadrangle Map GQ-74, scale 1:24,000. 
DeGraff, J.M., 2018, Keweenaw Fault Geometry, Secondary Structures, and Slip Kinematics along the Bête Gris Bay Shoreline, USGS EDMAP Final Technical Report: G17AC00115.

Foster, J.W., Whitney, J.D., Report on the Geology and Topography of a Portion of the Lake Superior Land District, Part I, Copper Lands. House Document, Thirty-first Congress, first session, 1849-1850, No. 69, p. 31.

Foster, J.W., Whitney, J.D., Age of the Sandstone of Lake of Superior, Description of the Phenomena of the Association of Igneous Rocks, Proceedings American Association for the Advancement of Science, Cincinnati Meeting, 1851, p. 29-30.

Hinze, W.J, Braile, L.W., 1990, A Geophysical Profile of the Southern Margin of the Midcontinent Rift System in Western Lake Superior: Tectonics, Vol. 9, No. 2, p. 303-310.

Irving, E.D. Chamberlin, T.C., 1885, Observations on the Junction Between the Eastern Sandstone and the Keweenaw Series on Keweenaw Point, Lake Superior, Bulletin of the United States Geological Survey, No. 23.

Jackson, C.T., 1849-1850, Senate documents, Thirty-first Congress, first session, Vol. III, p. 398,399 .

Kalliokoski, J., 1982, 7E: Jacobsville Sandstone: Geological Society of America Memoirs, 56; p.147-156

Miller, J., Nicholson, S., 2013, Geology and Mineral Deposits of the 1.1BA Midcontinent Rift in the Lake Superior Region - An Overview. 
Papadakis, J. and Raza, S.N., 1954, Geology of the Bare Hill and Montreal River Areas, Keweenaw County, Michigan: Michigan College of Mining and Technology, Houghton, Michigan, M.S. Thesis, p. 83.

Schultz, K. 2018, personal communication.

Trekas, D. 2019, Paleomagnetic Investigation of Igneous Rocks Deformed by the Keweenaw Fault in the Northwestern Keweenaw Peninsula: Michigan Technological University, Houghton, Michigan, M.S. Thesis. 